\title{
GOOD MINING PRACTICE DENGAN SISTEM ONLINE SEBAGAI SUPPORT PENERAPAN TAMBANG YANG ELEGAN DI SINARMAS MINING SITE KUANSING INTI MAKMUR, MUARO BUNGO, JAMBI
}

\author{
Dedy Waliyan \\ Mine Operation, Sinarmas Mining Site KIM \\ dedywaliyan@gmail.com, dedy.waliyan@ sinarmasmining.com
}

\begin{abstract}
ABSTRAK
Good Mining Practice (GMP) atau kaidah teknik pertambangan yang baik adalah suatu kegiatan pertambangan yang mentaati aturan, terencana dengan baik, menerapkan teknologi yang sesuai yang berlandaskan pada efektifitas dan efisiensi, melaksanakan konservasi batubara, mengendalikan dan memelihara fungsi lingkungan, menjamin keselamatan kerja, mengakomodir keinginan dan partisipasi masyarakat, menghasilkan nilai tambah, meningkatkan kemampuan dan kesejahteraan masyarakat sekitar serta menciptakan pembangunan yang berlanjutan. Penerapan kaidah teknik pertambangan yang baik pada pengusahaan mineral dan batubara sebagaimana amanat UU No. 4 Tahun 2009 tentang Pertambangan Mineral dan Batubara, salah satunya adalah melaksanakan kewajiban pengelolaan keselamatan dan kesehatan kerja pertambangan serta pengelolaan dan pemantauan lingkungan pertambangan. Implementasi amanat undang-undang tersebut harus diiringi komitmen yang tinggi untuk melindungi keselamatan pekerja dan operasi pertambangan, paralel dengan upaya perlindungan serta pencegahan terjadinya gangguan terhadap lingkungan hidup. Dalam implementasi praktek pertambangan yang baik dan benar ini, semua pihak (Pemerintah, pelaku bisnis, dan masyarakat) harus berperan aktif dan saling melakukan kontrol. Berdasarkan UU No. 4 Tahun 2009 tentang Pertambangan Mineral dan Batubara, ada beberapa ciri good mining practice, beberapa diantaranya adalah kepedulian terhadap Kesehatan dan Keselamatan Kerja (K3) serta keselamatan operasi pertambangan dan penerapan prinsip konservasi sumberdaya dan cadangan. Dalam realisasi program good mining practice di lingkungan PT Kuansing Inti Makmur (KIM), maka dibuat manual book dan checklist sebagai acuan untuk melakukan standardisasi dan perapian tambang yang elegan. Dalam penerapan awal, diperoleh kesulitan karena merupakan hal baru bagi Pengawas. Setelah program berjalan 1 bulan, maka menjadi biasa. Di bulan pertama, yaitu Juli 2018, perolehan persentase GMP di PT KIM sangat kecil, yaitu hanya $61 \%$ saja. Padahal target minimal yang harus dicapai adalah $85 \%$. Kemudian dilakukan upaya sosialisasi dan sharing mengenai aspek penilaian GMP. Setelah itu dilakukan improvisasi antara Tim Mine Operation dan Mitra Kerja di lapangan sehingga di Semester II Tahun 2018 bisa tercapai sesuai target, yaitu 85\%.

Di area industri 4.0 diperlukan metode paling efektif dan efisien sekaligus menerapkan value Sinarmas yaitu continuous improvement sehingga memudahkan Tim Mine Operation dalam realisasi good mining practice di lingkungan PT KIM. Maka dibuat GMP online, yaitu Pengawas dapat melakukan submit item checklist good mining practice dengan sistem online, yaitu melalui komputer ataupun handphone. Hal ini sangat mempermudah bagi Tim Mine Operation karena yang biasanya harus mengisi checklist form diatas kertas saat di lapangan, dengan tool ini menjadi lebih mudah dan cepat dengan sekali klik saja pada link GMP online maka sudah bisa langsung mengisi untuk melakukan penilaian.
\end{abstract}

Kata kunci : good mining practice, standardisasi, perapian tambang, online system. 


\begin{abstract}
Good Mining Practice (GMP) is a mining activity that obeys rules, is well planned, applies appropriate technology based on effectiveness and efficiency, carries out coal conservation, controls and maintains environmental functions, guarantees work safety, accommodates the desire and participation of the community, generating added value, increasing the ability and welfare of the surrounding community and creating sustainable development. The application of good mining technical principles to the exploitation of minerals and coal as mandated by Law No. 4 of 2009 concerning Mineral and Coal Mining, one of which is to carry out the obligation to manage the safety and health of mining work and to manage and monitor the mining environment. Implementation of the mandate of the law must be accompanied by a high commitment to protect the safety of workers and mining operations, in parallel with efforts to protect and prevent disruption to the environment. In the implementation of good and correct mining practices, all parties (The Government, business people, and communities) must play an active role and exercise mutual control. Based on Law No. 4 of 2009 concerning Mineral and Coal Mining, there are several characteristics of good mining practice, some of which are concern for Occupational Health and Safety (OHS) as well as the safety of mining operations and the application of the principle of conservation of resources and reserves. In the realization of a good mining practice program within PT Kuansing Inti Makmur (KIM), a manual book and checklist are made as a reference for standardization and an elegant mine fireplace. In the initial application, difficulties were obtained because it was new to Supervisors. After the program runs for 1 month, it becomes normal. In the first month, July 2018, the percentage of GMP at PT KIM was very small, only $61 \%$. Even though the minimum target that must be achieved is $85 \%$. Then an effort was made to socialize and share aspects of GMP assessment. After that an improvisation was made between the Mine Operation Team and the Partners in the field so that in Semester II 2018 it could be achieved on target, which is $85 \%$.

In the industrial area 4.0, the most effective and efficient method is needed while applying Sinarmas value, namely continuous improvement, making it easier for the Mine Operation Team to realize good mining practice within PT KIM. So GMP is made online, which is the Supervisor can submit good mining practice checklist items with the online system, namely through a computer or mobile phone. This makes it very easy for the Mine Operation Team because those who usually have to fill in the checklist form on paper while in the field, with this tool become easier and faster with just one click on the GMP online link then it can immediately fill out to make an assessment.
\end{abstract}

Keywords: good mining practice, standardization, mine face improvement, online system.

\title{
A. PENDAHULUAN
}

Sinarmas Mining merupakan salah satu pilar Sinarmas Group yang bergerak di bidang eksplorasi, penambangan, dan pemasaran batubara. Pertambangan batubara Sinarmas Mining tersebar dibeberapa wilayah di Indonesia, yaitu Kalimantan Timur, Kalimantan Selatan, Kalimantan Tengah, Jambi, dan Sumatera Selatan. Sinarmas Mining memiliki reputasi unggul dan terpercaya sebagai penyalur batubara dengan kualitas untuk support kepentingan dalam negeri maupun ekspor ke beberapa negara seperti India, Cina, Korea, Jepang, Taiwan, Filipina, Spanyol, dan negaranegara lain. Keunggulan Sinarmas Mining adalah harga batubara yang diproduksi dan biaya kirim yang lebih murah bagi pelanggan di Asia. Hal ini disebabkan oleh lokasi pertambangan di Indonesia yang diuntungkan secara geografi. Sebagai perusahaan yang berfokus pada pelanggan, Sinarmas Mining terus menjalankan kepatuhan, membekali diri dengan semangat kepemimpinan dan selalu siap menghadapi dinamika perubahan maupun tantangan demi tercapainya pertumbuhan yang berkelanjutan. Semangat yang eksponensial menjadikan Sinarmas Mining senantiasa inovatif, berorientasi pada masa depan, dan proaktif. Akselerasi transformasi membuat Sinarmas Mining 
terus menjadi yang terdepan, profesional, dan progressif. Pengembangan pengalihragaman energi terus digalakkan agar generasi yang akan datang dapat menuai masa depan yang cemerlang. Salah satu anak perusahaan Sinarmas Mining yaitu PT Kuansing Inti Makmur (KIM) dimana lokasi pertambangannya berada di Muaro Bungo, Provinsi Jambi.

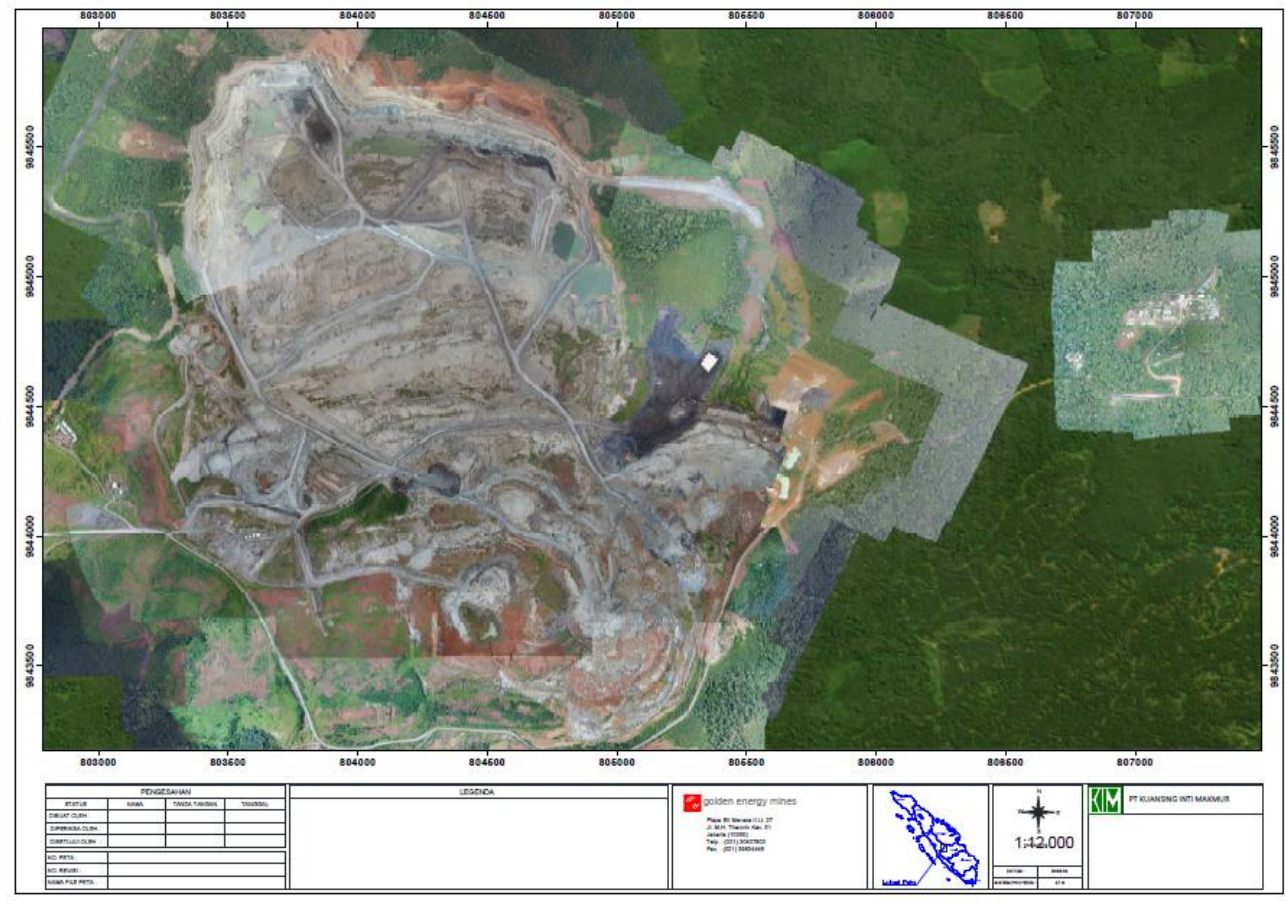

Gambar 1. IUP PT Kuansing Inti Makmur (KIM)

Produk batubara PT KIM dihasilkan dari metode penambangan open cut dengan kalori batubara 4.650 - $4.800 \mathrm{Kcal} / \mathrm{Kg}$ GAR yang merupakan produk primadona untuk pasar di Asia. Batubara hasil penambangan PT KIM yang telah ditumpuk di Run of Mine (ROM) kemudian diangkut menuju lokasi pelanggan tetap PT KIM menggunakan jalur darat dengan unit dump truck, yaitu ke Perawang dengan jarak $380 \mathrm{Km}$, ke Padang dengan jarak $250 \mathrm{Km}$, ke Lontar dengan jarak $265 \mathrm{Km}$, dan ke Nilau dengan jarak 304 Km (Gambar 2). 


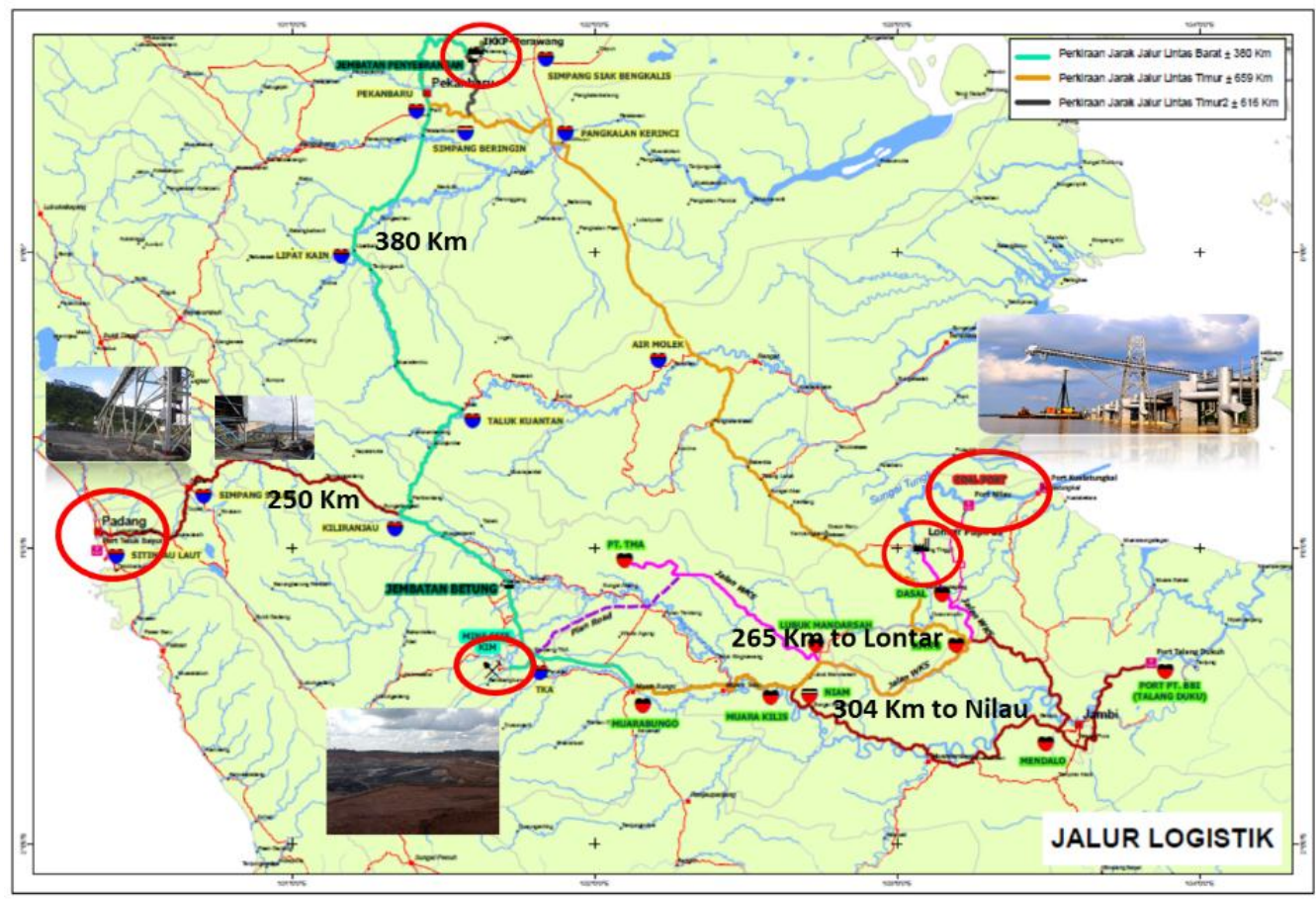

Gambar 2. Rute Pengiriman Penjualan Batubara PT Kuansing Inti Makmur (KIM) Di site KIM terdapat dua tambang yang telah dibuka, yaitu Pit East dan Pit West (Gambar 3). Dimana saat ini yang sedang aktif adalah Pit East.

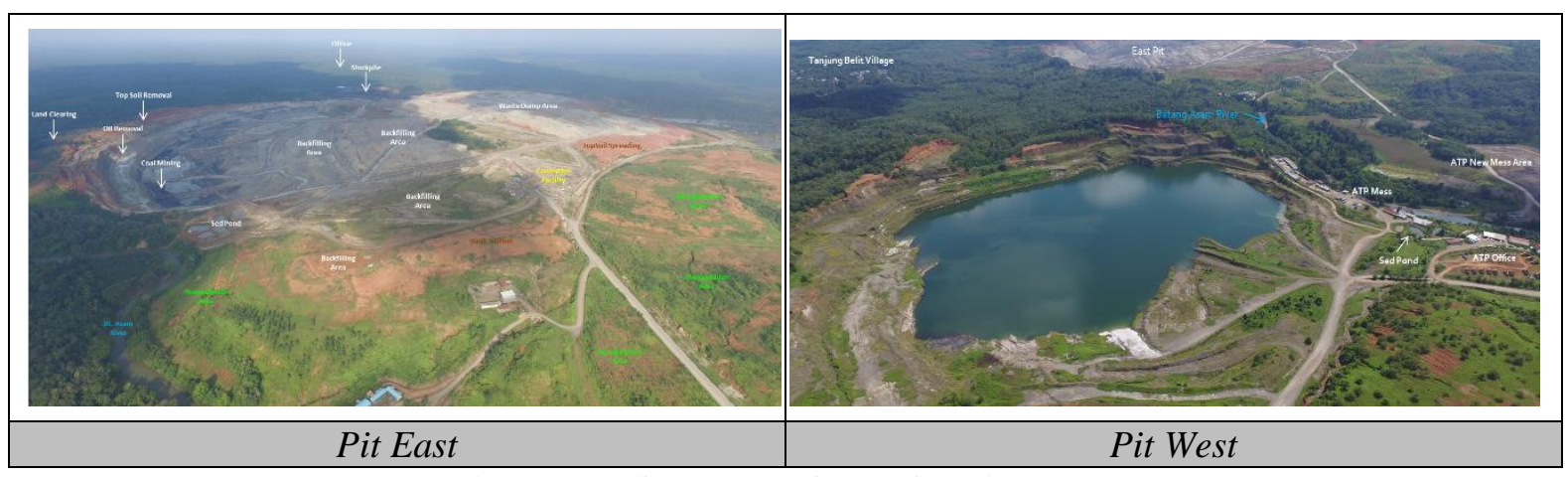

Gambar 3. Pit di PT Kuansing Inti Makmur (KIM)

Total cadangan saat ini berdasarkan hasil perhitungan pada akhir Tahun 2018 mencakup semua pit adalah sebesar 480.171.095 BCM untuk overburden dan sebesar 53.455.493 Ton untuk batubara dengan stripping ratio sebesar 8,98. Dimana stripping ratio rendah berada di Pit West, yaitu sebesar 8,53 dan stripping ratio tinggi berada di Pit East yang sedang dikerjakan saat ini, yaitu sebesar 10,25 (Tabel 1).

Tabel 1. Cadangan

\begin{tabular}{|l|c|r|r|r|}
\hline End of 2018 Reserve & & \multicolumn{1}{|c|}{ KIM WEST } & \multicolumn{1}{c|}{ KIM EAST } & \multicolumn{1}{l|}{ TOTAL } \\
\hline Quantity & & & & \\
\hline Waste & $\mathrm{Mbcm}$ & $335,428,488$ & $144,742,607$ & $480,171,095$ \\
\hline Coal & $\mathrm{Mt}$ & $39,334,683$ & $14,120,810$ & $53,455,493$ \\
\hline Stripping Ratio & $\mathrm{bcm} / \mathrm{t}$ & 8.53 & 10.25 & 8.98 \\
\hline
\end{tabular}

Sejak Tahun 2013, PT KIM terus meningkatkan produksinya baik untuk coal getting maupun coal hauling. Namun, tidak dapat dihindari dengan kondisi tambang yang semakin dalam dan lebar, maka tentunya mengakibatkan banyaknya volume overburden yang harus dikupas sehingga 
memberikan efek stripping ratio yang terus meningkat. Dimana pada puncaknya di akhir Tahun 2018, PT KIM mencapai produksi batubara dari pit ke ROM sebesar 2,17 Juta Ton dan pengiriman batubara dari ROM ke buyer sebesar 2,38 Juta Ton. Tentunya hal ini dicapai dengan banyaknya juga volume overburden yang telah digali yaitu sebesar 18,93 Juta BCM dengan stripping ratio sebesar 8,72. Dimana angka tersebut mengalami peningkatan dibandingkan 5 tahun sebelumnya terutama pada Tahun 2013 dengan pencapaian produksi batubara dari pit ke ROM sebesar 1,97 Juta Ton, pengiriman batubara dari ROM ke buyer sebesar 2,02 Juta Ton, overburden yang digali sebesar 15,53 Juta BCM, dan stripping ratio sebesar 7,88 (Gambar 4 dan Gambar 5).

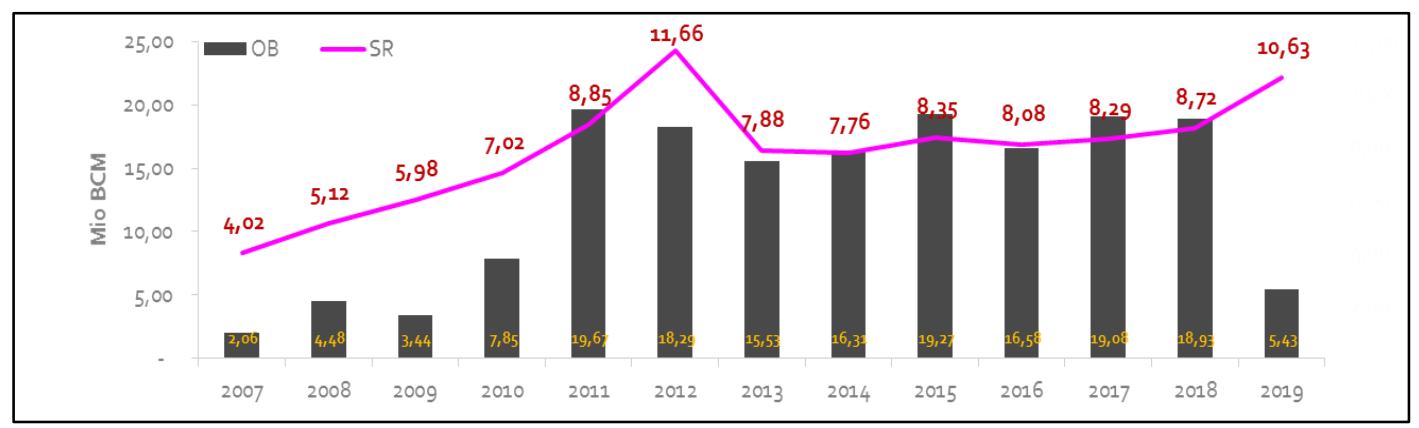

Gambar 4. Pencapaian Produksi Overburden dan Stripping Ratio PT Kuansing Inti Makmur (KIM)

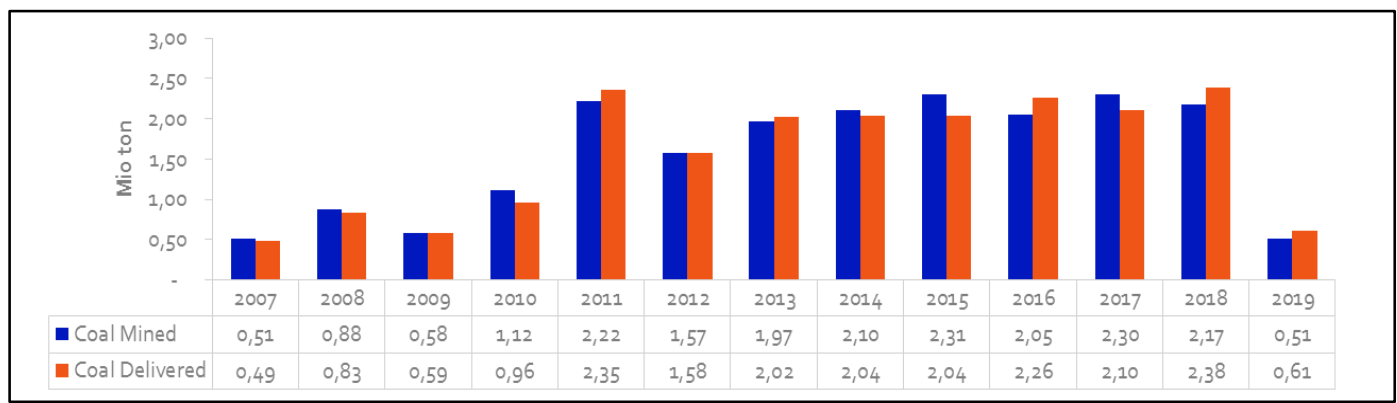

Gambar 5. Pencapaian Coal Mined dan Coal Delivered PT Kuansing Inti Makmur (KIM)

Seperti perusahaan pertambangan batubara ideal lainnya, PT KIM juga melakukan aktivitas dari mulai eksplorasi dan pengeboran hingga pada akhirnya dihasilkan model geologi dan design yang aman dan produktif. Setelah itu dilakukan pembersihan lahan, pengupasan tanah pucuk (Top soil), pengeboran dan peledakan, pengupasan lapisan tanah penutup (Overburden), dumping material top soil maupun overburden, penggalian batubara, pemuatan dan pengangkutan batubara dari pit ke $R O M$, dan akhir proses bisnis yaitu pemuatan dan pengangkutan batubara dari ROM ke buyer (Gambar 6). Adapun kualitas produk batubara yang dihasilkan oleh PT KIM dan menjadi asupan rutin buyer yaitu dengan kisaran kalori sebesar 4.650 - $4.800 \mathrm{Kcal} / \mathrm{Kg}$. Di tambang PT KIM terdapat tiga lapisan batubara yang diambil, yaitu Seam 100, Seam 200, dan Seam 300 (Gambar 7).

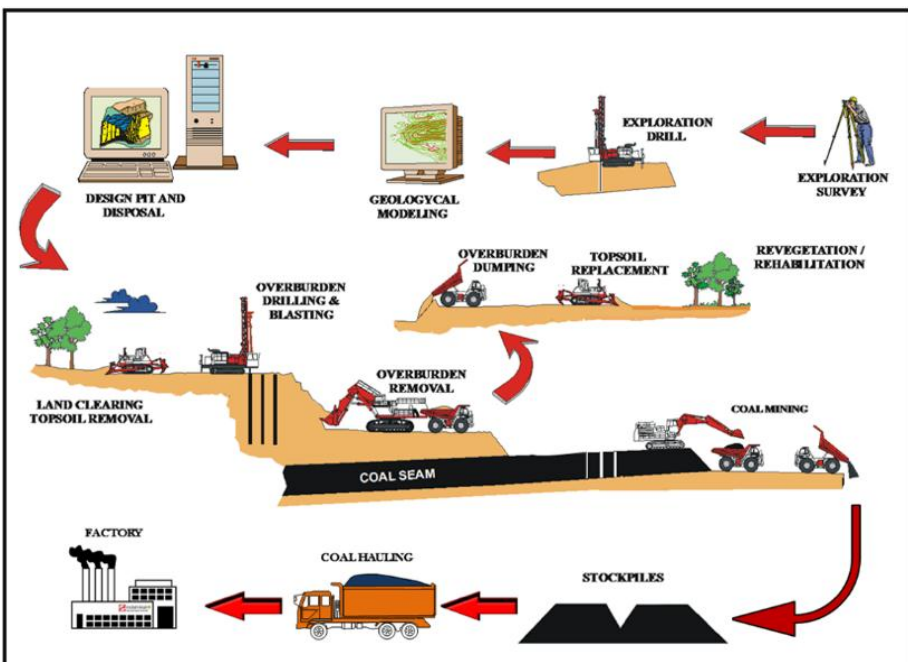


Gambar 6. Aktivitas Pertambangan PT Kuansing Inti Makmur (KIM)

Dalam Undang-Undang No. 4 Tahun 2009 disebutkan bahwa dalam pertambangan wajib menjalankan teknis penambangan sesuai kaidah good mining practice. Dalam Undang-Undang tersebut juga mengatur lima aspek penting yang harus diperhatikan untuk dapat menjalankan kegiatan pertambangan dengan baik dan benar (Good mining practice). Di antaranya, keselamatan dan kesehatan kerja (K3) pertambangan, keselamatan operasi pertambangan, pengelolaan dan pemantauan lingkungan pertambangan, termasuk reklamasi dan pascatambang. Aspek lain yang juga krusial ialah usaha konservasi sumber daya mineral dan batu bara, pengelolaan sisa tambang dari suatu kegiatan usaha pertambangan baik, serta memenuhi baku mutu lingkungan.

Melihat aspek-aspek tersebut, artinya teknik pertambangan bukan semata-mata menata tambang menjadi rapi, melainkan juga mengedepankan keselamatan dan kesehatan kerja (K3), keselamatan operasi (KO) dan lingkungan, serta sustainable mining dengan melakukan konservasi terhadap sumber daya yang ditambang.

Pada 2018 pemerintah telah berupaya terus meningkatkan pengelolaan pertambangan menjadi lebih apik, yakni dengan dikeluarkannya Peraturan Menteri ESDM No 26/2018 tentang Pelaksanaan Kaidah Pertambangan yang Baik dan Pengawasan Pertambangan Minerba. Disertai pula Keputusan Menteri ESDM No 1827 K/30/MEM/2018 tentang Pedoman Pelaksanaan Kaidah Teknik Pertambangan yang Baik dan merupakan petunjuk pelaksanaan dari UU Minerba sebagai payung hukum dalam pelaksanaan kegiatan pertambangan minerba. Dalam implementasinya, praktik pertambangan yang baik dan benar harus memperhatikan beberapa hal. Misalnya, eksplorasi harus dilaksanakan dengan baik dan memadai, ada perhitungan cadangan layak tambang, serta studi-studi mengenal kondisi geografis dan dampak terhadap lingkungan.

Sinarmas memiliki 6 nilai perusahaan yang disebutkan dalam lagu Hymne Sinarmas yang sering diperdengarkan pada setiap orang yang memasuki head office Sinarmas di Sinarmas Land Plaza Jakarta (Gambar 8). Salah satu shared value tersebut adalah continuous improvement (Perbaikan berkelanjutan), yaitu Meningkatkan kemampuan/kapasitas diri, unit kerja dan organisasi secara terus menerus tanpa batas untuk mencapai hasil terbaik, melalui data yang akurat, peduli biaya, dan proses unggul. 

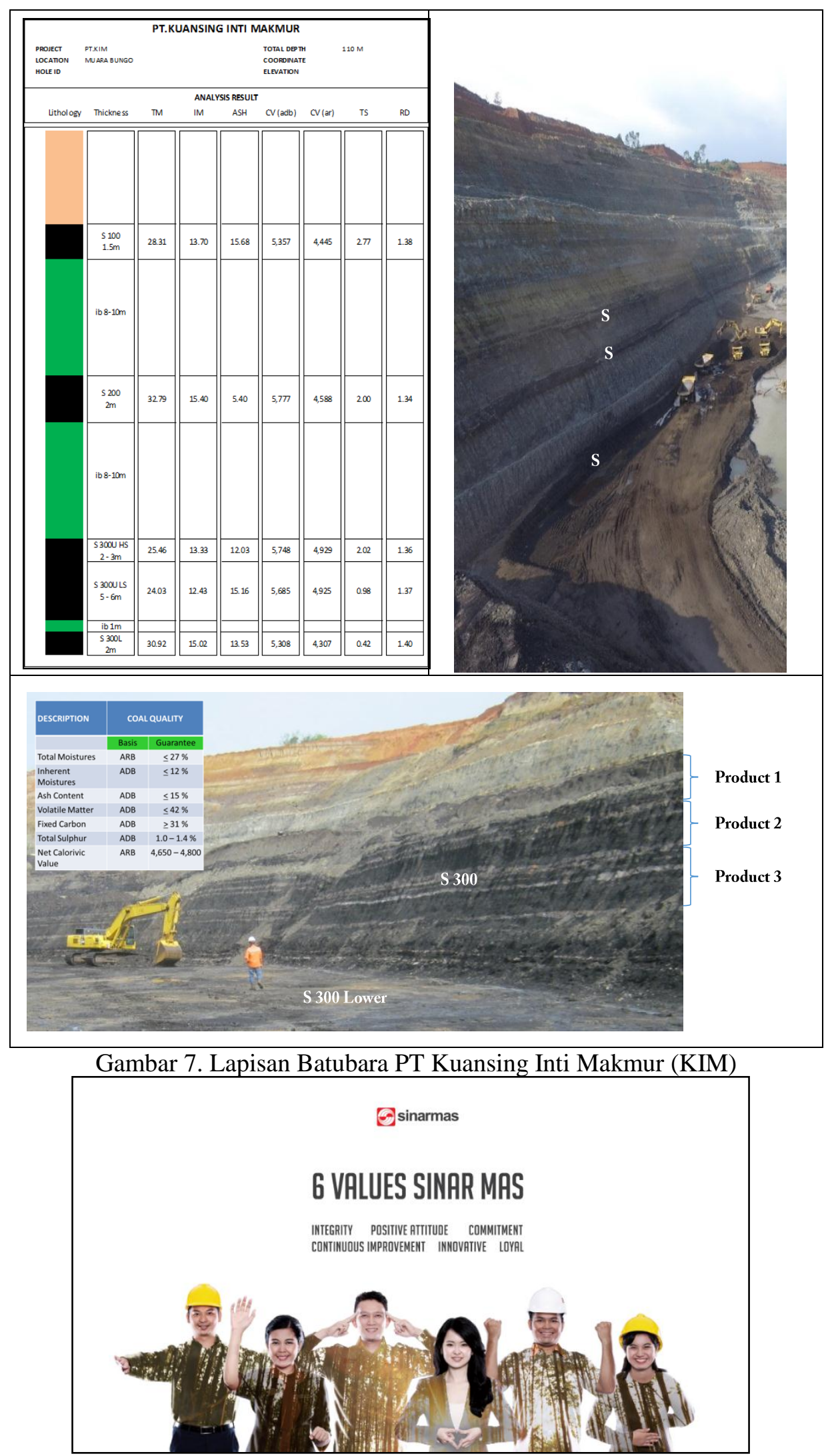

Gambar 8. Shared Values Sinarmas

Mengacu pada hal tersebut diatas, maka Tim Mine Operation PT KIM membuat improvement untuk penerapan good mining practice di lapangan. Karena dari semua pemangku kepentingan di 
Sinarmas Mining tentunya sepakat dan berharap bahwa dengan pencapaian good mining practice maka akan menciptakan tambang yang produktif, aman, dan elegan.

\section{B. METODOLOGI PENELITIAN}

Metodologi yang digunakan dalam menyusun penelitian ini adalah metode deskriptif, yaitu metode yang digunakan untuk mencari unsur-unsur, ciri-ciri, sifat-sifat suatu fenomena. Metode ini dimulai dengan mengumpulkan data, menganalisis data, dan menginterpretasikannya. Penggunaan metode deskriptif dalam penerapan good mining practice di lingkungan tambang PT KIM yaitu dengan melakukan pengawasan melekat oleh Tim Mine Operation di lapangan secara harian pada hal-hal terkait good mining practice, seperti drainase, pita acuan loading, lebar front loading, dan lain-lain. Semua temuan dicatat dalam form inspeksi standar HSE Department PT KIM.

Karena item pada checklist form inspeksi tidak memenuhi semua item berkenaan dengan good mining practice, maka dibuatlah manual book dan checklist mengenai good mining practice sebagai acuan untuk melakukan standardisasi dan perapian tambang yang elegan. Untuk sebulan pertama, yaitu Juni 2018, pengumpulan data lapangan berdasarkan manual book dan cheklist yang ada dilakukan oleh Pengawas dari Tim Mine Operation sekaligus sosialisasi program GMP ke Pengawas Mitra Kerja. Setelah itu kemudian program ini disosialisasikan kembali di level manajemen PT KIM dengan Mitra Kerja dalam Pertemuan Komite Keselamatan Pertambangan pada Bulan Juni 2018 (Gambar 9).

Setelah itu disosialisasikan kembali kepada Pengawas Mitra Kerja. Perlu waktu hingga akhir bulan Juni 2018. Kemudian mulai record data saat realisasi program GMP di bulan Juli 2018 dan review secara continue hingga akhir Tahun 2018.

\section{HASIL DAN PEMBAHASAN}

Pada Juni 2018 mulai dilakukan realisasi program GMP namun perlu waktu 1 shift kerja full (Estimasi 8 jam) untuk mengambil sampel acak data, baik di front loading OB, front loading coal, disposal, dan mine haul road. Karena di lapangan bukan hanya dilakukan pencatatan, namun juga dilakukan pengawasan ada atau tidak adanya deviasi terhadap manual book yang telah dibuat. Kemudian juga dilakukan koordinasi dengan Pengawas Mitra Kerja untuk langsung dilakukan perbaikan. Jika ada yang belum dimengerti, maka dilakukan sosialisasi kembali oleh Pengawas dari Tim Mine Operation PT KIM.

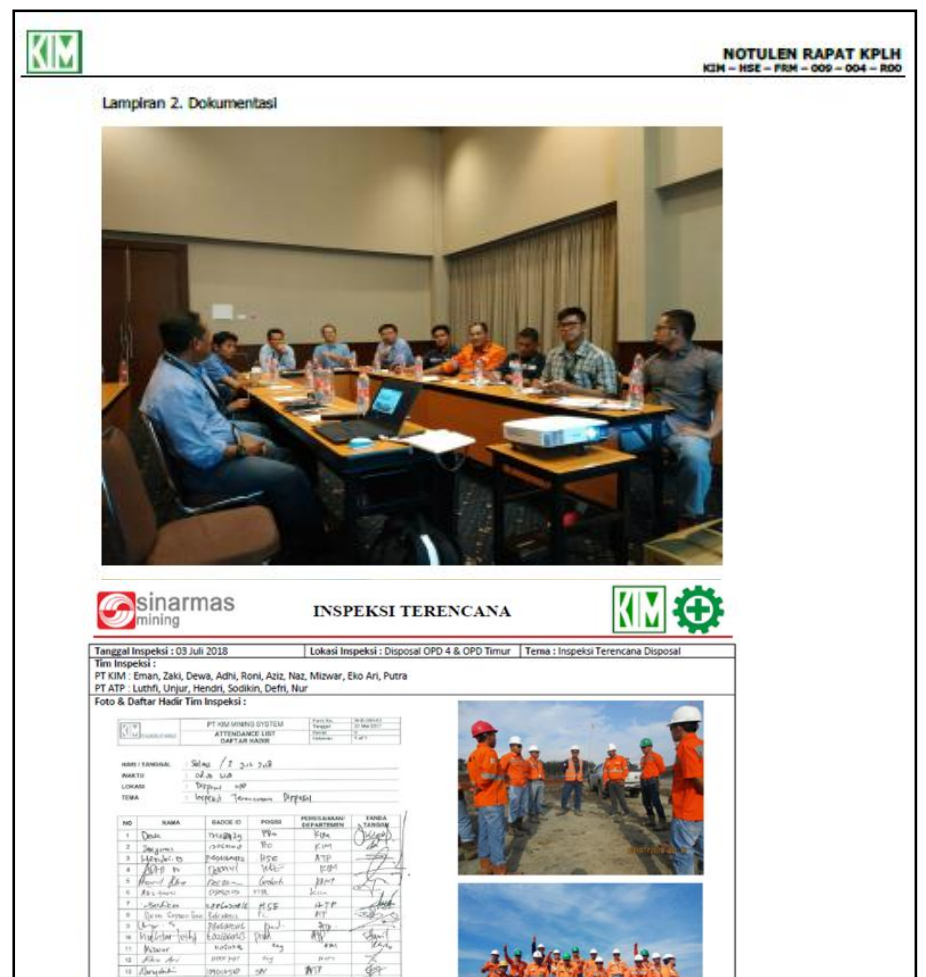


Gambar 9. Sosialisasi Program GMP dalam Pertemuan Komite Keselamatan Pertambangan dan dalam Forum Inspeksi Terencana di Lapangan

Kondisi tersebut tentu sangat menyulitkan Tim Mine Operation PT KIM dalam melakukan record data karena perlu effort lebih lagi untuk memasukkan data lagi ke komputer diluar jam kerja. Setelah itu baru bisa dilakukan perhitungan persentase pencapaian GMP di tiap-tiap area.

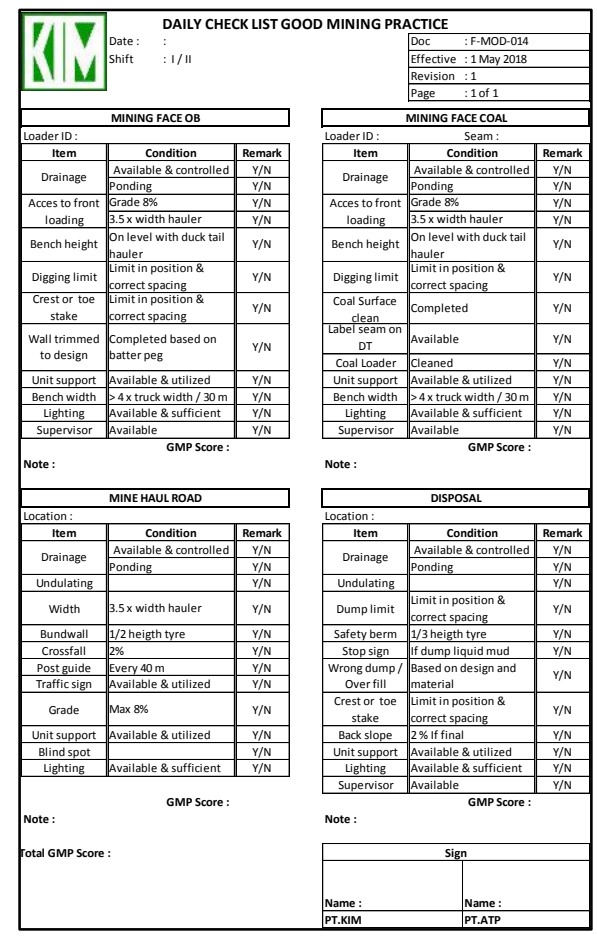

Gambar 10. Form Daftar Periksa Manual Good Mining Practice

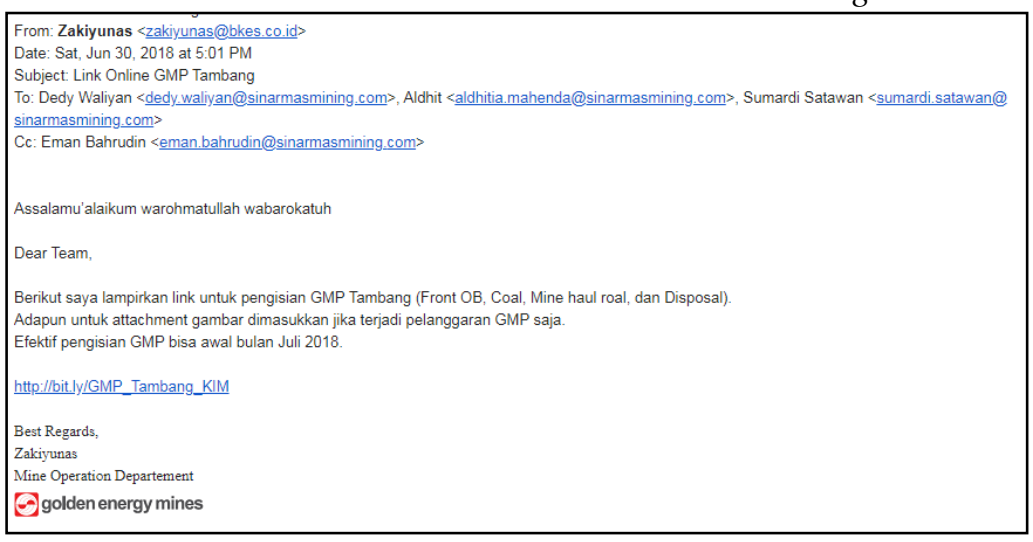

Gambar 11. Sosialisasi Program GMP Secara Online Melalui Link di E-mail 
Di area industri 4.0 diperlukan metode paling efektif dan efisien sekaligus menerapkan value Sinarmas yaitu continuous improvement sehingga memudahkan Tim Mine Operation dalam realisasi good mining practice di lingkungan PT KIM. Maka dibuat sistem dari GMP manual (Gambar 10) menjadi GMP online (Gambar 12 dan Gambar 13), yaitu Pengawas dapat melakukan submit item checklist good mining practice dengan sistem online, yaitu melalui komputer ataupun handphone. Hal ini sangat mempermudah bagi Tim Mine Operation karena yang biasanya harus mengisi checklist form diatas kertas saat di lapangan, dengan tool ini menjadi lebih mudah dan cepat dengan sekali klik saja pada link GMP online maka sudah bisa langsung mengisi untuk melakukan penilaian.

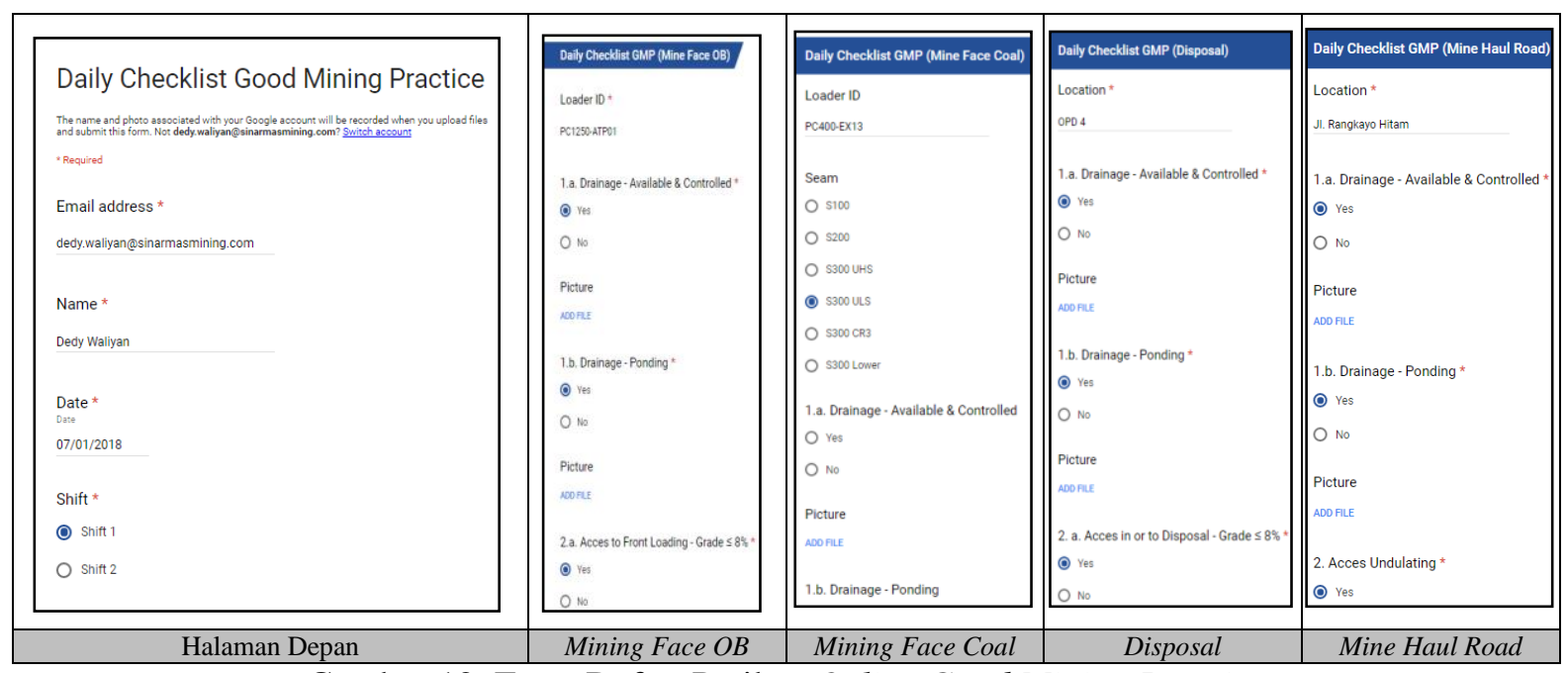

Gambar 12. Form Daftar Periksa Online Good Mining Practice

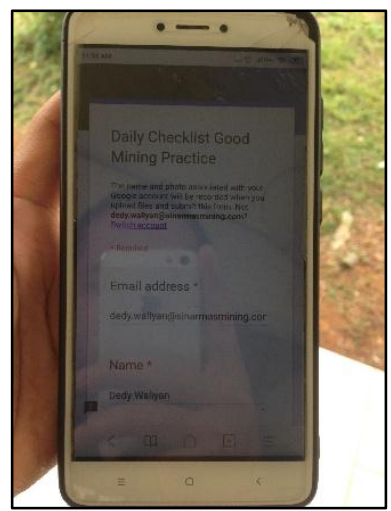

Gambar 13. Tampilan Isian Daftar Periksa pada Telepon Seluler

Dengan sistem online, pengawasan terhadap GMP di lapangan menjadi efektif dan efisien sehingga Pengawas dari Tim Mine Operation PT KIM bisa melakukan pengawasan dengan fokus lain atau melakukan improvisasi lain. Pengawasan dan pengisian hanya perlu dilakukan 4 jam per shift. Pengisian data pun selesai hanya dalam 1 menit. Dengan demikian, Pengawas tidak perlu melakukan penulisan data manual, mengurangi penggunaan kertas, data dapat dilihat secara cepat dan lebih menarik karena sudah berupa data excel dengan dilengkapi foto, tidak perlu submit dan hitung data setelah selesai jam kerja, dan lebih banyak waktu bagi Pengawas untuk melakukan analisa dan improvisasi terhadap setiap deviasi (Gambar 14).

\begin{tabular}{|c|c|c|c|c|c|}
\hline \multicolumn{1}{|c|}{ GMP Manual } \\
\hline $\begin{array}{c}\text { 1.Kopi darat } \\
\text { dengan Pengawas }\end{array}$ & $\begin{array}{c}\text { 2.Mengisi GMP } \\
\text { checklist form } \\
\text { secara manual }\end{array}$ & $\begin{array}{c}\text { 3.Rekomendasi } \\
\text { perbaikan terhadap } \\
\text { deviasi GMP }\end{array}$ & $\begin{array}{c}\text { 4.Membuat rekap } \\
\text { data dari form ke } \\
\text { database GMP }\end{array}$ & $\begin{array}{c}\text { 5.Melakukan } \\
\text { review terhadap } \\
\text { semua data GMP }\end{array}$ & $\begin{array}{c}\text { Tools: Form, alat } \\
\text { tulis, komputer }\end{array}$ \\
\hline
\end{tabular}




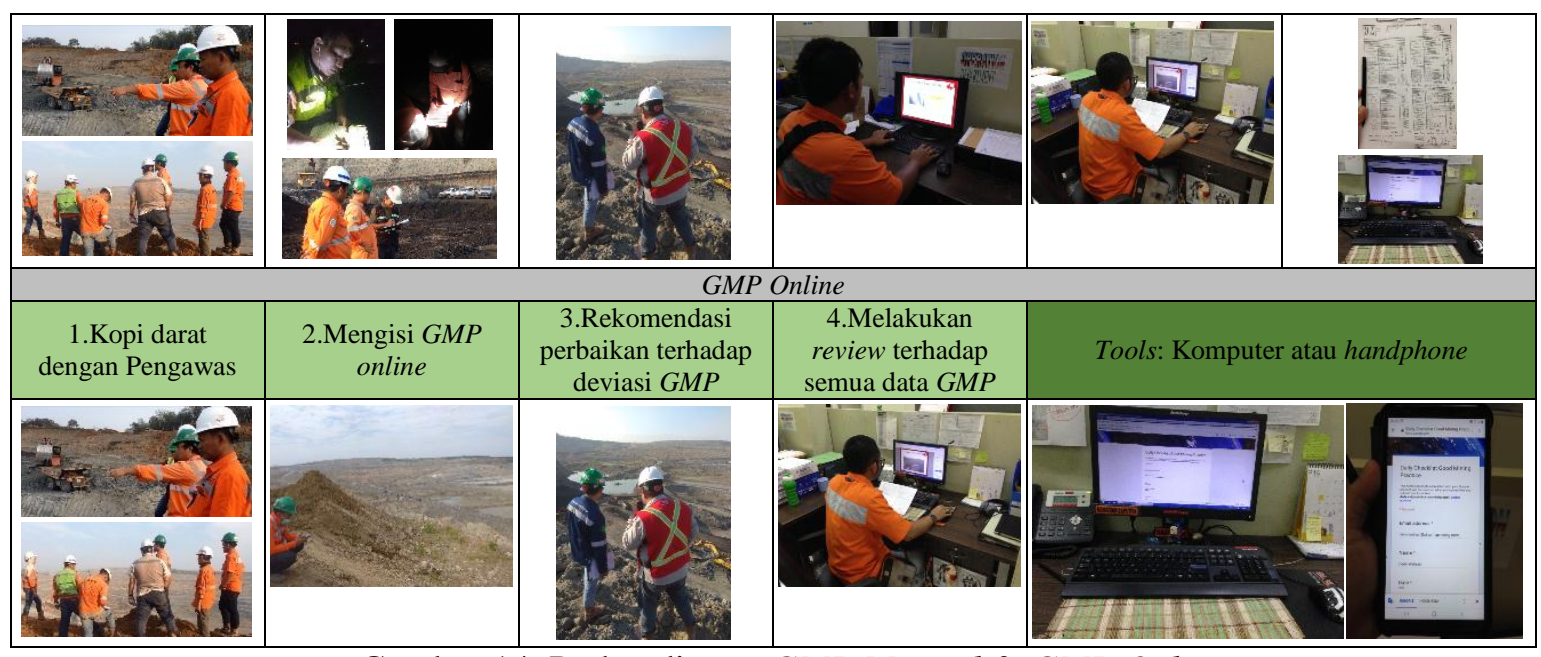

Gambar 14. Perbandingan GMP Manual \& GMP Online

Data yang diperoleh dari GMP online pada Juli 2018 dengan target pencapaian 85\% adalah sebesar $61 \%$ saja. Dengan detail sebagai berikut :

1. Mining face $O B$ sebesar $58 \%$, yang menjadi deviasi adalah drainase, grade jalan ke front loading, lebar jalan inlet front loading, tinggi dan lebar bench, ketersediaan unit dozer, dan patok acuan loading.

2. Mining face coal sebesar $60 \%$, yang menjadi deviasi adalah drainase, grade jalan ke front loading, lebar jalan inlet front loading, tinggi bench, dan ketersediaan unit dozer.

3. Disposal sebesar $62 \%$, yang menjadi deviasi adalah undulasi pada inlet akses, safety berm atau windrow, dan patok acuan dumping.

4. Mine haul road sebesar 64\%, yang menjadi deviasi adalah undulasi pada akses, lebar jalan, bundwall, dan guide post.

Dengan deviasi angka tersebut, maka dilakukan lagi sosialisasi isi manual book GMP termasuk penerapan di lapangan dan dilakukan pengawasan melekat untuk mengawal terealisasinya program ini hingga akhir tahun 2018. Setelah itu, dilakukan lagi review pada Semester II Tahun 2018 dengan pencapaian rata-rata sesuai target yang ditentukan di semua area yaitu sebesar $85 \%$ (Gambar 15). 


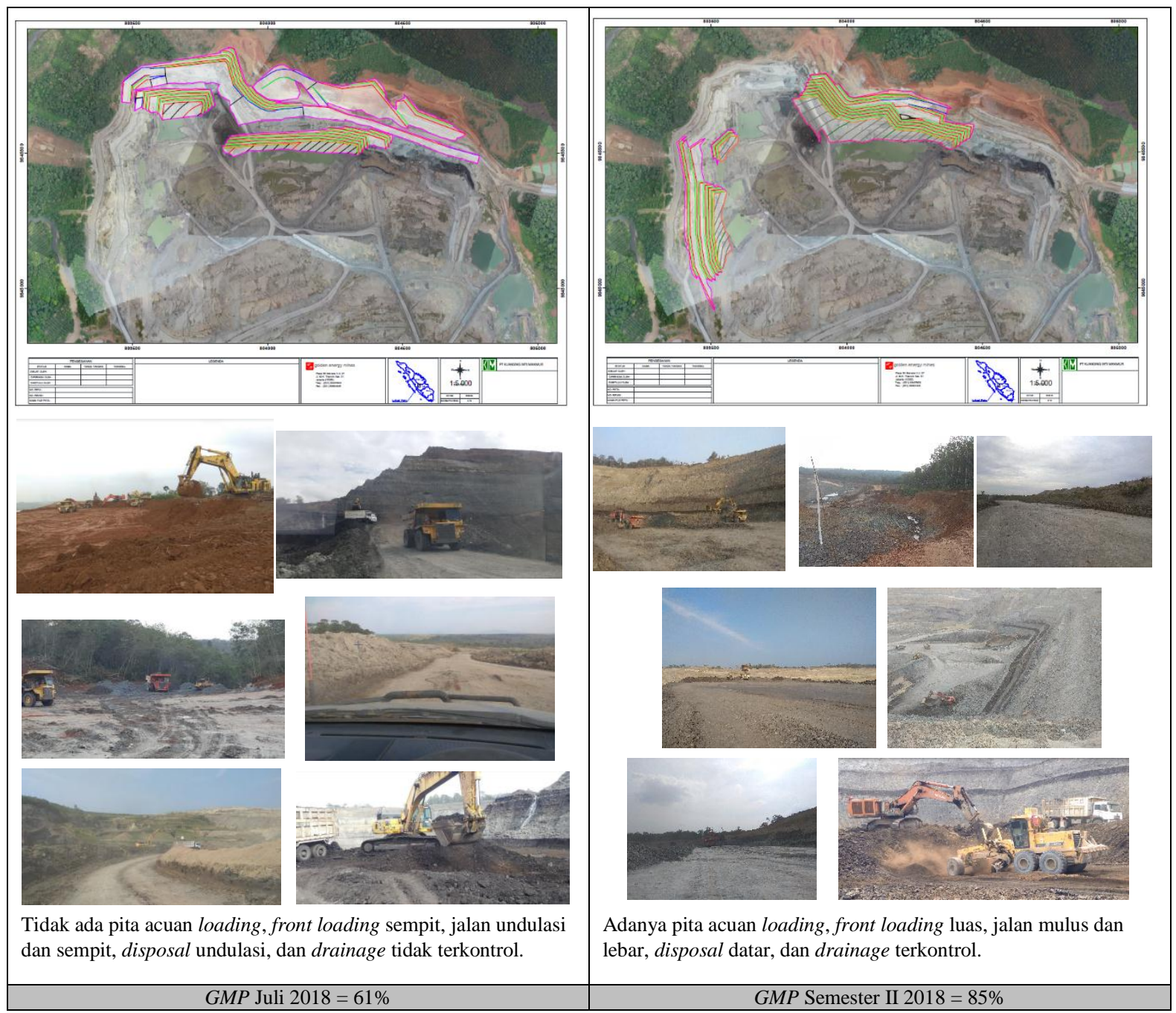

Gambar 15. Perbandingan Pencapaian Good Mining Practice pada Tahun 2018

\section{KESIMPULAN}

Dari tulisan diatas dapat disimpulkan bahwa :

1. Good mining practice perlu diterapkan di setiap tambang sebagai bentuk kepatuhan terhadap regulasi pemerintah. Selain itu adalah untuk menciptakan tambang yang aman, produktif, dan elegan.

2. Di era industri 4.0, dalam setiap pekerjaan dituntut untuk serba cepat, tepat, akurat, mudah, dan up to date terhadap teknologi.

3. Untuk menerapkan good mining practice di Sinarmas Mining site KIM, maka dibuat program GMP online oleh Tim Mine Operation. Dengan program ini, Pengawas tidak perlu melakukan penulisan data manual, mengurangi penggunaan kertas, output data dapat dilihat secara cepat dan lebih menarik karena sudah berupa data excel dengan dilengkapi foto, tidak perlu submit dan hitung data setelah selesai jam kerja, dan lebih banyak waktu bagi Pengawas untuk melakukan analisa dan improvisasi terhadap setiap deviasi. Dengan hanya sekali klik menggunakan komputer ataupun telepon genggam, semua Pengawas bisa mengakses untuk menjalankan program GMP online.

\section{UCAPAN TERIMAKASIH}


Sebagai penulis makalah ini, saya mengucapkan rasa syukur dan terimakasih kepada :

1. Allah 'azza wa jalla yang telah memberi berjuta nikmat tiada tara dan Rasulullah yang telah mencerdaskan umat manusia dari kejahilan.

2. Mutiara Anwar Wanatami dan Abizar Utsman Shaquell, dua cinta yang Allah titipkan kepada saya sebagai salah satu media menggapai surga, yang tiada batas selalu mensupport dengan senyum dan doa untuk saya.

3. Hartoby Zulhiansyah selaku Mine Operation Manager yang telah men-support terealisasinya program GMP online ini dengan menggunakan power beliau sebagai atasan.

4. Zakiyunas dan Aldhitia Mahenda selaku Tim Huru-Hara yang telah bersama-sama berjuang membuat dan merelisasikan langsung di lapangan sehingga pelan tapi pasti program GMP online dapat terjadi sesuai rencana.

5. Adhi Wiyanto selaku HSE Section Head dan Tim Kerja yang mau mengangkat program ini dalam safety commitee meeting level tertinggi di PT KIM sehingga tersosialisasikan dengan baik dan bisa seiring sejalan dan berhubungan dengan program Pro Active Safety Target yang menjadi program handalan Tim HSE.

6. Semua Tim di PT KIM yang telah mendukung dengan data dan doa sehingga makalah ini dapat diselesaikan dengan baik.

\section{DAFTAR PUSTAKA}

2018. Data Produksi Tahun 2018. Tanjung Belit: PT Kuansing Inti Makmur.

2018. Data Quality Control Tahun 2018. Tanjung Belit: PT Kuansing Inti Makmur.

2018. Laporan Hasil Inspeksi Tahun 2018. Tanjung Belit: PT Kuansing Inti Makmur.

2019. Induksi Karyawan PT KIM Tahun 2019. Tanjung Belit: PT Kuansing Inti Makmur. 
PROSIDING TPT XXVIII PERHAPI 2019 